\title{
SIGNS AND TRENDS IN SOCIOECONOMIC CHANGES IN RURAL AREAS
}

\author{
Eugeniusz Niedzielski, Full Professor ${ }^{1}$ \\ Faculty of Economics, University of Warmia and Mazury in Olsztyn
}

\begin{abstract}
This paper analyses the scope and the main directions of economic and social changes occurring in rural areas including, among others, the declining role of agriculture and the growth of non-agricultural activity. Although employment in agriculture is decreasing, the population of people in rural areas is on the rise, while the general population continues to decline. In general, these phenomena have been caused by nationwide deurbanisation and re-ruralisation (the influx of residents to rural areas). The cumulative effect of these changes is the transformation of rural areas, especially those which are suburban or attractive due to their natural environment, which are losing their agrarian character.
\end{abstract}

Keywords: rural areas, functions of rural areas, economic and social changes

JEL code: R11

\section{INTRODUCTION}

Traditional thinking identifies the countryside with agriculture and, in terms of production, this association is likely to remain valid forever. However, modern times are characteristic for their overarching volatility, which also affects the functions of rural areas, the scope, signs, conditions and consequences of the occurring changes. After the change in the political system in 1989, rural areas have undergone considerable production-related, economic, social and cultural shifts, deemed comparable to, or greater than, the changes that have transpired in other socio-economic spheres. At the same time, the countryside had a far worse starting point than the city (the industry). At the beginning of the transformation, the countryside and agriculture were not areas of particular interest for the state or the socioeconomic policy. Both the opening of the markets and the dwindling state support have decreased the profitability of food production and reduced the income of the rural population. The living conditions worsened with the shutdown of some of the social infrastructure facilities, the so-called supply and sale cooperatives, and cuts in the transport network. This transformation was particularly painful for the former state farms and rural areas, where a high percentage of property was state-owned. This stagnation, or rather recession, in the growth of rural areas was put to a halt after Poland's accession to the European Union. Even before, the countryside had received support from pre-accession programmes, but it was only after the introduction of the common European agricultural policy that farmers gained access to direct subsidies and, under a range of dedicated programmes, the rural population could receive funds for restoring the infrastructure and developing

${ }^{1}$ Corresponding author: Oczapowskiego 2, 10-719 Olsztyn, Poland, koiz@uwm.edu.pl, +4889 5233498 
the non-agricultural economic activity. This paper aims to outline the economic and social processes and phenomena observed in the countryside, as well as the signs which forecast its future.

\section{ECONOMIC ACTIVITY}

Identifying the countryside solely with agriculture is an increasingly inaccurate reflection of reality. The number of so-called agricultural homesteads, which engage in solely agricultural activity, amounts to approximately 300 thousand. In other words, only one homestead in seven has sufficient commercial production to generate a decent income to ensure development. According to the report drafted by the Country Support Foundation (FWW), the number of people living on agriculture barely exceeds $10 \%$ of the rural population, $38 \%$ of people engage in hired labour, while $25 \%$ live on pensions and benefits, and the remainder have diversified sources of income (Sadura, 2017). Approximately $40 \%$ of rural homesteads are unrelated to agriculture.

The survival of many homesteads, not only those engaging in commercial production, is ensured by direct subsidies from the European Union, which are used by more than 1.3 million homesteads. Those subsidies are provided in the form of social pensions which complement the income generated by a limited agricultural production. Although in Poland the share of subsidies in agricultural income is lower than in other countries of western Europe, it has reached $50 \%$. The total amount of the subsidies in the years 2004-2015 amounted to EUR 21 billion. Differing capability to use the subsidies, develop agricultural production and compete in the market has significantly polarised the acreage of homesteads. There is a clear increase in the number of small, so-called 'social' homesteads (up to $2 \mathrm{ha}$ ) and large commercial homesteads covering an area of more than 50 ha.

While the gap in the spatial distribution of agricultural production continues to grow, reaching the level of regional specialisation, the scale of poverty and disparities in the level of income among the rural population are decreasing (Wilkin and Nurzyńska, 2016). Large-scale homesteads, most of which are situated in regions where a high percentage of property used to be state-owned, specialise in field crop production, sometimes combined with factory farming, while smaller homesteads engage in a multi-faceted activity or specialise in gardening, ecological production or traditional husbandry. The liberalisation of international trade in agricultural produce will foster the concentration of production and an increase in acreage as a prerequisite for competitiveness. In other cases, it may encourage the development of market niches which exploit unique natural assets or technological conditions for production. The concentration of agricultural production, involving factory animal farming or large-scale monocultures, complicates the fulfilment of requirements related to sustainable development, especially in the field of natural sustainability. In the social dimension, sustainable development involves using available labour resources and providing the rural residents with access to products and services which determine the standard of their living conditions. The growth of such activity has encountered multiple barriers, such as scarcity of demand, its dispersion across a large territory, low level of education, lack of experience in business activity and legal limitations, especially for small food service facilities, food production and direct sales. Studies have found that rural residents engaging in nonagricultural activity have a lower level of education than farmers, especially the owners of larger homesteads (Zawalińska et al., 2015). Such residents have more difficulty finding employment as hired workers or initiating their own economic activity. Yet, some of the educated youth return to rural areas. Those people show potential to start their own economic activity, either in the form of self-employment or a microenterprise. People engaging in such businesses are often families of the farmers. Sometimes, nonagricultural and agricultural activity is combined, as exemplified by agritourism. Non-agricultural economic activity comprises different areas (industries) of manufacturing and services, usually involving trading (oftentimes street trading), construction and repairs, food processing, small-scale manufacturing (handicrafts), tourism, vehicle servicing and transport (Sadura, 2017). The growth of non-agricultural entrepreneurship may be fuelled by the increasing influx of urban residents to the countryside. However, 
this process is more likely to generate demand for all kinds of services (housework, gardening, cultural services, beauty services, etc.); migrants should not be expected to launch their own businesses. In general, the countryside is progressively losing is agrarian character (though the speed of changes varies) while its non-agricultural functions keep growing (Rosner and Stanny, 2016). Those processes are in line with the principle of multi-functional rural development. Changes in the economic structure are coupled with social development because of the growing social and technical infrastructure, public services, use of labour resources, upkeep of homesteads and agriculture. The development of non-agricultural economic activity in the countryside:

- prevents marginalisation and depopulation of rural areas, especially those located on the peripheries;

- ensures better allocation and use of capital and human resources on a regional and local scale;

- increases the standard and quality of living by generating income and allowing rural residents to satisfy their needs in terms of livelihood, culture, recreation, production, transport, etc.;

- improves the accessibility of public services thanks to the growing social and technical infrastructure, financed with municipal income generated by business;

- spreads knowledge of the economy and fosters entrepreneurship.

In general, even though agriculture is losing its significance due to the dwindling employment and share in GDP, it remains vital for using land resources and ensuring food security. At the same time, non-agricultural activity in rural areas continues to grow in importance. The relationships between those two spheres of economic activity show considerable spatial disparity: for instance, they are different in rural areas bordering agglomerations and on the peripheries.

\section{SOCIAL CHANGES}

Since the change to a market system, and later the accession to the European Union, rural areas have witnessed significant demographic and social changes. Those changes have translated into, among other things, a growth in the rural population, even as the general population continues to decrease. The growing number of rural residents is the upshot of migration from the cities. The scale of this migration is more than sufficient to balance out the migration to the cities and abroad, as well as the dwindling birth rate of the rural population (Zawalińska et al., 2015). Currently, approximately $40 \%$ of the general population lives in the countryside and this percentage is on the rise. Living in the countryside seems more and more attractive. It is usually the wealthier and the educated who move to rural areas, while the opposite direction is taken by people who have lesser economic and professional potential (Sadura, 2017). Thus, the gap in the intellectual potential between the country and the city is closing. Migrants from the cities settle in places located in vicinity of urban areas. Villages bordering a city often become commuter towns. In addition, urban dwellers migrate to places appealing due to their scenic landscapes or allowing them to pursue their dreams of an idyllic life in the bosom of nature. More and more people combine living in the country and the city by means of second-home ownership (Stanny and Drygas, 2010). Discovering rural areas as a good place for settling down often leads to re-ruralisation, or a return to living in the country. It is a symptom of tendencies opposite to those observed on a global scale. In most Polish cities, the number of inhabitants is declining. In other words, de-urbanisation is underway. The changing employment structure of rural residents, involving a decreasing share of people involved in agricultural production, is a symptom showing that rural areas are losing their agrarian character. Judging by the manner and scope of integration of urban dwellers with the rural environment, two groups may be discerned: animators and colonists (Bendyk, 2017). Members of the former group socialise with the local community and initiate activities which lead to mobilisation of the people and development of the area. Such activities may be related to history, tradition, rural customs, economic activity (e.g. traditional food, ecological farming, agritourism) or social activity (associations, cooperatives, etc.). Conversely, colonists refrain from integrating with the local population. They often only exploit local resources, including cheap labour, to achieve their own goals (Bendyk, 2017). 
Rural areas are losing their agrarian character and the process of re-ruralisation continues. As a result, almost $46 \%$ of rural homesteads are owned by workers (engaging in hired labour), $34 \%$ by pensioners, $6 \%$ by businessmen and less than $12 \%$ by farmers (Nurzyńska and Poczta, 2014). Shifts in the social and employment structure of rural population, increased incomes (due to direct subsidies, among others) and the development of social and technical infrastructure financed with European funds have narrowed the gap between the country and the city. It is apparent from the amenities of rural homesteads, accessibility of services, transport possibilities and the level of education. The scope of changes also shows high spatial disparity (Stanny and Drygas, 2010). In peripheral areas, where the distance to the closest city is significant, the geographic location is unfavourable (e.g. near the Russian border) or the transport possibilities are limited, agriculture remains the main function in terms of production, depopulation continues and villages virtually disappear. In turn, in the vicinity of large agglomerations, the borders and differences between the country and the city become blurred, resulting in the emergence of a country-city unit. In peripheral areas, the share of the elderly is increasing due to migration, poverty is relatively common and the number of so-called NEETs (not in employment, education or training) remains relatively high. The growing diversity and multi-culturality of the rural population have a positive potential, as the cooperation of multicultural subjects and their mutual influence generate a synergistic effect. On the other hand, diversity and multi-culturality pose a risk for rural traditions and the integration of local communities. Those circumstances necessitate support for traditional rural organisations, initiatives to ensure educational chances, especially in disadvantaged areas, the development of economic co-operation (cooperatives, producer groups, etc.) and the development of non-governmental organisations.

\section{TOWARDS SUSTAINABLE DEVELOPMENT}

The economic and social changes discussed have various causes and consequences. The identification of all the causes is difficult, if not impossible. Even though they are always rooted in the past, and - as time cannot be stopped - the present has also already changed into the past where we seemingly have full (or at least broad) knowledge, identification of the sources of changes and their relationships to the current situation presents a range of considerable challenges. This is because not only causal relationships need to be considered, but also feedback loops, the multiplier effect, the synergistic effect, and others. Furthermore, rural areas are not isolated from their closer and more distant surroundings - including the entire globe - in various spheres (economic, political, civilisational, etc.). Predicting the consequences, or the future, is an even more difficult task. This cumulative uncertainty results from the growing volatility which stymies any predictions of the future. The problem concerns the favourability assessment of different aspects of changes, including the assessment of conformity with the principles of sustainable development. The economy should satisfy social needs and its principles, as well as the manner of satisfying those needs, should be in harmony with the natural environment. The awareness of risks for the ecosystem posed by economic growth is becoming increasingly universal. It is the consequence of, among others, environmental threats resulting from industrialisation of plant and animal production, concentration of production and reduction of biodiversity (Niedzielski, 2015). Preserving harmony with the natural environment is becoming an even more arduous task due to the abovementioned spatial disparity of homesteads. Growing population density and the development of rural areas further aggravates the problem. Sustainable development requires interventionism at the level of the state and local governments since the pursuit of economic gain may clash with social and environmental interests, the development of technical infrastructure and settling may damage the landscape and nature, etc. Ecological awareness, as well as concern for biodiversity, scenic landscapes, quality of natural environment (soil, water, air) are also required and, fortunately, are increasing in society. Economic and social changes in rural areas are increasing the diversity of functions served by those territories, thus developing the network of relationships between those functions. 


\section{CONCLUSIONS}

In recent decades, particularly since the Polish accession to the European Union and the implementation of the common agricultural policy, rural areas have witnessed far-reaching economic and social changes. Three processes are the cause and the effect of those changes: de-urbanisation, re-ruralisation and the loss of agrarian character by rural areas. The fading role of agriculture in rural areas has translated into decreasing employment in agriculture, dwindling acreage of land used for farming, as well as a rapid growth in non-agricultural economic activity. Social and cultural changes result from the altered number and structure of rural residents, which include more and more actual inhabitants (second homes) or former urban dwellers (migrants). The scope and direction of changes, both in the economic and the social dimension, show high spatial disparity - ranging from areas with a very limited agricultural function, located in the vicinity of large agglomerations, to peripheral areas, where depopulation is widespread and agricultural prevails along with forestry.

\section{REFERENCES}

1. Bendyk, E. (2017). Ile wsi we wsi [How many villages in the village]. Polityka, 43, pp. 15-18.

2. Niedzielski, E. (2015). Funkcje obszarów wiejskich i ich rozwój [Features of rural areas and their development]. Zagadnienia Ekonomiki Rolnej, 2, pp. 85-92.

3. Nurzyńska, I., Poczta, W. (eds.) (2014). Polska wieś 2014. Raport o stanie wsi [Polish village 2016. Report on the state of the village]. Scholar, Warszawa.

4. Rosner, A., Stanny, M. (2016). Monitoring obszarów wiejskich. Etap II [Monitoring of rural areas. Stage II]. IRWiR PAN, Warszawa.

5. Sadura, P. (ed.) (2017). Wieś w Polsce 2017. Diagnoza i prognoza. Raport z badań [Village in Poland 2017. Diagnosis and forecast. Research report]. Fundacja Wspomagania Wsi, Warszawa, pp. 15-22.

6. Stanny, M., Drygas, M. (2010). Przestrzenne społeczno-ekonomiczne zróżnicowanie obszarów wiejskich w Polsce [Spatial socio-economic diversity of rural areas in Poland]. IRWiR PAN, Warszawa.

7. Wilkin, J., Nurzyńska, I. (eds.) (2016). Polska wieś 2016. Raport o stanie wsi [Polish village 2016. Report on the state of the village]. Scholar, Warszawa.

8. Zawalińska, K. et al. (2016). Polska wieś wobec wyzwań rozwoju społeczno-gospodarczego w świetle badań IRWiR PAN w latach 2014 i 2015 [Polish countryside in the face of the challenges of socio-economic development in the light of IRWiR PAN research in 2014 and 2015]. Wieś i Rolnictwo, 3, pp. 164-168. 